\title{
Field evaluation of different new fungicides against rust disease of fieldpea (Pisum sativum L.)
}

\author{
R. L. SHARMA*, TUSHAR MISHRA ${ }^{1}$, RAKESH BHAGAT ${ }^{1}$ AND VIVEK KUMAR SWARNKAR ${ }^{1}$ \\ Krishi Vigyan Kendra (I.G.K.V.), RAIPUR (CHHATTISGARH) INDIA \\ ${ }^{1}$ Krishi Vigyan Kendra (I.G.K.V.), Gariyaband, RAIPUR (CHHATTISGARH) INDIA
}

\section{ARITCLE INFO \\ Received : 01.02 .2017 \\ Revised : 27.03 .2017 \\ Accepted : 31.03 .2017}

\section{KEY WORDS :}

Fieldpea, Fungicides, Rust disease, Yield, Yield attributes

*Corresponding author: ramlaxmansharma@yahoo.com

\begin{abstract}
The present study was conducted during consecutive Rabi season of year 2012-13 and 2013-14 at farmers field of village Potiya in Gariyaband district of Chhattisgarh plains to test efficacy of some new fungicides in controlling rust diseases of fieldpea. Results revealed that Propiconazole + cyproconazole (330 EC) recorded highest reduction of rust disease incidence before $2^{\text {nd }}$ spray, before $3^{\text {rd }}$ spray and after $3^{\text {rd }}$ spray of fungicides and was found significantly superior as compared to other tested fungicides followed by azoxystrobin $250 \mathrm{SC}$ and difenoconazole $250 \mathrm{SC}$. Highest per cent disease incidence was recorded with untreated control plot. As far as other observations regarding yield and yield attributing characteristics of fieldpea, Propiconazole + cyproconazole (330 EC) recorded highest plant height, length of pods, breadth of pods, number of pods plant ${ }^{-1}$, number of seeds pod $^{-1}, 1000$ seed weight and seed yield of fieldpea followed by azoxystrobin $250 \mathrm{SC}$ and difenoconazole $250 \mathrm{SC}$. Lowest yield and yield attributes was found with untreated control.
\end{abstract}

How to view point the article : Sharma, R.L., Mishra, Tushar, Bhagat, Rakesh and Swarnkar, Vivek Kumar (2017). Field evaluation of different new fungicides against rust disease of fieldpea (Pisum sativum L.). Internat. J. Plant Protec., 10(1) : 186-192, DOI : 10.15740/HAS/IJPP/10.1/ 186-192. 